\title{
PERILAKU TOKOH INDIGO DALAM NOVEL DANUR KARYA RISA SARASWATI : KAJIAN PSIKOLOGI SASTRA
}

\author{
Siti Fatimah Astari ${ }^{\bowtie}$, U’um Qomariyah, Maharani Intan Andalas \\ Jurusan Bahasa dan Sastra Indonesia, Fakultas Bahasa dan Seni, Universitas Negeri Semarang, \\ Indonesia
}

\section{Info Artikel}

\section{Sejarah Artikel:}

Diterima Januari 2019

Disetujui Februari 2019

Dipublikasikan Maret 2019

\section{Keywords:}

Indigo character, Behavior Novel Danur

\begin{abstract}
Abstrak
Salah satu fenomena yang terjadi dalam kehidupan manusia adalah masalah kejiwaan sehingga berpengaruh terhadap perilakunya kepada orang lain. Hal itulah yang dialami tokoh Risa dalam novel karya Risa Saraswati yang berjudul Danur. Peristiwa-peristiwa yang dialami membuat tokoh Risa berperilaku sesuai dengan apa yang telah disaksikannya. Perilaku tokoh Risa dihadapkan pada konflik psikologis yang dipengaruhi oleh lingkungan. Penelitian ini bertujuan untuk (1) mendeskripsikan karakteristik tokoh utama sebagai seorang indigo, (2) mendeskripsikan tokoh indigo dalam merespon stimulus tokoh lain, (3) mendeskripsikan perkembangan kepribadian tokoh indigo dalam Danur karya Risa Saraswati. Pendekatan yang dilakukan dalam penelitian ini adalah psikologi sastra, yang dikhususkan pada psikologi behavior, yaitu teori yang membahas aspek perilaku dan perkembangan kepribadian. Berdasarkan hasil penelitian, diketahui bahwa, (1) terdapat karakteristik indigo pada tokoh Risa, meliputi: berkemauan keras, keras kepala, kreatif dengan bakat artistik pada musik, bertindak berdasarkan intuisi atau psikis, cenderung mengalami insomnia dan mimpi buruk, memiliki riwayat depresi dan pikiran- pikiran atau upaya bunuh diri, mencari persahabatan yang sejati, mendalam, dan bertahan lama. (2) perilaku tokoh Risa merupakan respon yang terbentuk dari stimulus yang dapat diterima oleh alat indra mata, telinga, dan mulut (3) perkembangan kepribadian Risa berkaitan dengan kelima sahabatnya. Hal tersebut terbukti pada peristiwa tokoh Risa sebelum mengenal kelima sahabatnya, mengenal, ditinggalkan dan bertemu kembali dengan kelima sahabatnya.
\end{abstract}

\begin{abstract}
One of the phenomena that occur in human life is a matter of psychological abuse so that the effect on their behaviour to others. That is experienced by a character in the novel by Risa Risa Saraswati entitled Danur. The events that make the character Risa behave in accordance with what she had. The behavior of the character Risa is exposed to psychological conflict that is affected by the environment. This research aims to (1) describe the characteristics of the main character as an indigo, (2) describe the indigo's character of stimulus respond to another, (3) describe the development of the personality of the characters in the works of Risa Saraswati. The approach was conducted in this research is the psychology literature, which specialized in psychology behavior, that is the theory that discusses aspects of behavior and the development of personality. Based on the results of the research, noted that, (1) there are characteristics of indigo on the character Risa, include: strong-willed, stubborn, creative with artistic talent in music, Act on intuition or psychic, are likely to experience insomnia and nightmares, have a history of depression and thoughts of suicide attempts, or looking for a true friendship, profound, and enduring. (2) the behaviour of the character Risa is a response that is formed from a Stimulus that can be accepted by the appliance senses eyes, ears and mouth (3) development of personality related to Risa's fifth bestfriends. this has proven by the condition when the character doesn't know yet her bestfriends, knows, left behind, and finally meet her fifth bestfriends again.
\end{abstract}


Siti Fatimah Astari / Jurnal Sastra Indonesia 8 (1) (2019)

(C) 2019 Universitas Negeri Semarang

Alamat korespondensi:

ISSN 2252-6315

Gedung B1 Lantai 1 FBS Unnes

Kampus Sekaran, Gunungpati, Semarang, 50229

E-mail: fatimahastari93@gmail.com 


\section{PENDAHULUAN}

Karya sastra erat kaitannya dengan kehidupan. Karya sastra adalah suatu karya hasil pemikiran atau pengekspresian dari seorang pengarang. Setiap pengarang dalam menampilkan karyanya berbeda sebab mereka mempunyai ciri khas yang berbeda-beda. Meskipun terdapat perbedaan di antara pengarang yang satu dengan yang lain, permasalahan yang dibahas hampir sama, yaitu berbicara tentang kehidupan. Hal ini sesuai dengan pendapat Wellek dan Warren (1995:110) yang mengatakan bahwa sastra mencerminkan dan mengekspresikan hidup. Pengarang tidak bisa tidak mengekspresikan pengalaman dan pandangannya tentang hidup.

Novel merupakan salah satu bentuk karya sastra yang dapat menggambarkan pengalaman batin seorang pengarang dengan relatif rinci. Pengalaman batin pengarang berupa peristiwa atau masalah yang menarik sehingga muncul gagasan atau imajinasi yang dituangkan dalam bentuk tulisan. Pengarang mengembangkan cerita dalam novel melalui tokoh.

Tokoh-tokoh khususnya pada novel mempunyai perilaku yang berbeda-beda. Perilaku tersebut ada yang sesuai dengan norma sosial dan ada pula penggambaran perilaku tokoh yang tidak sesuai dengan norma yang berlaku di tengah masyarakat. Perilaku merupakan cerminan dari keadaan jiwa atau mental seseorang. Melalui perilaku, keadaan jiwa seseorang dapat dijelaskan. Perilaku yang melekat pada tokoh dapat dikaji dengan pendekatan psikologi sastra.
Peneliti memilih Danur untuk dikaji dengan alasan sebagai berikut. Pertama, karya tersebut menggambarkan tokoh sebagai seorang indigo yang berkait dengan pengalaman batin pengarang. Risa sebagai seorang indigo memiliki perspektif atau pandangan berbeda mengenai kehidupan lain di luar dunianya. Selain itu, Risa memiliki perilaku empati yang tinggi disebabkan kepekaan yang berlebih pada lingkungannya.

Kedua, perilaku tokoh Risa dihadapkan pada konflik psikologis yang dipengaruhi oleh lingkungan. Perilaku tokoh Risa pada Danur menggambarkan reaksi dalam mengahadapi lingkungan tokoh lain yang berada pada luar dunia nyata. Rangsangan dari dunia nyata dan luar dunia nyata yang dialami oleh Risa sangat berpengaruh pada perilakunya. Perilaku Risa yang dipengaruhi oleh lingkungan dapat menjadi petunjuk adanya unsur psikologi.

Ketiga, sepengetahuan peneliti, novel Danur belum pernah dikaji dengan pendekatan psikologi sastra. Terutama yang berhubungan dengan perilaku tokoh utama. Kajian terhadap novel Danur dengan menggunakan pendekatan psikologi sastra diperlukan untuk mengetahui perilaku Risa.

Berdasarkan uraian latar belakang di atas, novel Danur dapat dikaji untuk mengetahui perilaku tokoh utama dalam menerima stimulusstimulus dan merespon apa yang telah dialaminya melalui teori psikologi kepribadian B. F. Skinner.

\section{METODE PENELITIAN}

Pendekatan yang digunakan dalam penelitian ini adalah pendekatan psikologi sastra, 
yang mengkaji aspek psikologi tokoh indigo dalam novel Danur. Hal ini didasarkan pada fokus penelitian yang bertujuan mendriskripsikan ciriciri tokoh utama sebagai seorang indigo, mendeskripsikan tokoh indigo dalam merespon stimulus tokoh lain, dan mendeskripsikan perkembangan kepribadian tokoh indigo. Data yang dijadikan objek dalam penelitian ini adalah bagian teks yang terdapat pada novel Danur yang menunjukkan penggambaran perilaku tokoh indigo dalam merespon terhadap stimulus dari tokoh lain dan yang menunjukkan perkembangan kepribadian tokoh indigo. Sumber data dalam penelitian ini adalah novel yang berjudul Danur karya Risa Saraswati, yang diterbitkan Bukune, tahun 2011, cetakan pertama dengan tebal 216 halaman. Selain itu, buku yang berkaitan dengan psikologi dan sastra, seperti Teori Kepribadian oleh Syamsu Yusuf dan Juntika Nurihsan tahun 2008, Teori dan Pengukuran Pengetahuan, Sikap, dan Perilaku Manusia, oleh Wawan, A dan Dewi M tahun 2010, Identifikasi dan Penanganan bagi Anakanak Indigo, oleh Doreen Virtue tahun 2011, Sekitar Masalah Sastra: beberapa Prinsip dan Model Pengembangannya oleh Aminuddin tahun 1990.

Teknik pengumpulan data yang digunakan adalah teknik baca catat yaitu membaca dan memahami seluruh jalan cerita Karakteristik Tokoh Indigo novel Danur karya Risa Saraswati, kemudian mencatat hal-hal yang berkaitan dengan masalah yang akan diteliti. Pengumpulan data dalam penelitian ini yaitu dengan mencari dan menjelaskan ciri- ciri indigo, mencari dan menjelaskan tokoh indigo merespon stimulus tokoh lain, dan mencari dan menjelaskan perkembangan kepribadian tokoh indigo.
Dalam penelitian ini, teknik yang digunakan untuk menganalisis data yang telah diperoleh adalah teknik deskripstif kualitatif, yaitu memanfaatkan cara-cara penafsiran dengan menyajikan dalam bentuk deskripsi (Ratna, 2004: 46). Teknik ini sangat mendukung tercapainya tujuan penelitian, yaitu mendeskripsikan ciri-ciri tokoh tokoh utama sebagai seorang indigo, mendeskripsikan tokoh indigo merespon stimulus tokoh lain, dan mendeskripsikan perkembangan kepribadian tokoh indigo. Hasil analisis dideskripsikan berdasarkan data-data yang terkumpul, baik berupa kata, kalimat maupun paragraf yang terdapat dalam sumber data yakni pada novel Danur karya Risa Saraswati.

Teknik deskriptif kualitatif digunakan karena memang data-data dalam penelitian ini berupa kata, kalimat, atau paragraf yang berada di dalam cerita sehingga bentuknya data kualitatif. Penjelasan dilakukan secara deskriptif, dalam hal ini peneliti menampilkan penjelasan mengenai segala sesuatu yang menunjukkan adanya klasifikasi perilaku tokoh indigo dalam cerita novel.

\section{HASIL PENELITIAN DAN PEMBAHASAN}

\section{Karakteristik seorang indigo yang} tedapat pada tokoh utama meliputi berkemauan keras, keras kepala, kreatif dengan bakat artistik pada musik, bertindak berdasarkan intuisi atau psikis, cenderung mengalami insomnia dan mimpi buruk, memiliki riwayat depresi dan pikiran- pikiran bunuh diri, mencari persahabatan yang sejati, mendalam, dan bertahan lama. Karakteristik tokoh utama sebagai indigo ini 
Siti Fatimah Astari / Jurnal Sastra Indonesia 8 (1) (2019)

merupakan bentukkan dari lingkungan. Stimulus yang diterima tokoh Risa Karaktristik yang terdapat pada tokoh utama melalui alat indra mata berupa ruangan sepi, sebagai seorang indigo seluruhnya dipengaruhi kedatangan dan kebersamaan dengan kelima oleh lingkungan. sahabat, lahan kosong dan rindang, mendapatkan hadiah, kedatangan makhluk- makhluk halus,

Karakteristik dapat dibentuk melalui gangguan- gangguan dari makhluk halus. perilaku yang sering dilakukan. Perilaku Risa Stimulus yang diterima tokoh Risa memunculkan merupakan perilaku berkondisi. Perilaku respon sebagai berikut.

berkondisi yakni perilaku yang muncul sebagai

respon atas stimulus berkondisi. Perilaku Teman- teman di sekolah yang berkondisi bagian terbesar dari perilaku manusia menjailinya. Risa harus tinggal terpisah dengan dan kemungkinan untuk memodifikasi sangat orang tuanya. Risa dihadapkan dengan besar bahkan dapat dikatakan tidak terbatas. permasalahan yang terus berulang- ulang ia Karakteristik dibentuk dari perilaku Risa yang alami. Hal tersebut membuat ia mendapatkan sering dilakukan diperkuat oleh rangsangan dari stimulus yang diterima oleh mata berupa ruangan luar, sehingga perilaku Risa sesuai dengan sepi. Ruangan itu membuatnya nyaman dan rangsangan yang ia dapat. Rangsangan dari luar mampu meluapkan kekesalannya. Ruangan yang seperti gangguan dari makhluk tidak terlihat, mempertemukan Risa dengan kelima sahabatnya. teman- temannya di sekolah yang menjailinya, Berikut ini kutipan yang menunjukkan hal cerita- cerita dari makhluk tidak terlihat.

tersebut.

\section{Respon Tokoh Indigo terhadap Stimulus Tokoh Lain}

Perilaku manusia dipandang dalam bentuk hubungan stimulus dan respon. Perilaku manusia sebagai respon yang muncul kalau ada stimulus terntentu. Stimulus atau rangsangan adalah segala sesuatu yang dapat diterima oleh alat indra. Stimulus yang terdapat pada novel Danur dapat diterima oleh alat indra mata, telinga, mulut. Berdasarkan anggapan tersebut, perilaku tokoh indigo disikapi sebagai "respon" yang muncul karena ada "stimulus" dari tokoh lain.

\section{Stimulus Dapat Diterima oleh Alat Indra Mata}

" Kubanting tas sekolah dan menaiki tangga kayu menuju loteng sempit yang ada di atas garasi rumah nenekku, rumah yang kutinggali. Isak tangisku bisa bebas lepas keluar bahkan se kencangkencangnya di sana, karena memang letaknya yang agak jauh dari ruangan- ruangan lain."..."Aku duduk di pojok loteng sambil mendekap kaki dengan kedua tanganku, kepala menunduk rapat menempel pada lutut."(Danur 2011:12)

Kutipan di atas menjelaskan bahwa sifat Risa lemah. Perilaku Risa yang menangis dan ketakutan membentuknya menjadi seseorang yang pendiam, tidak suka berinteraksi dengan sesamanya. Perilaku pendiam ini membawanya ke pengetahuan baru bahwa ia mempunyai kelebihan mampu melihat makhluk- makhluk 
halus dan membawanya lebih nyaman mengarahkan pada hasil - hasil yang positif berinteraksi dengan makhluk- makhluk halus seperti kebiasan mereka yang selalu bersama, dibandingkan dengan manusia pada umumnya.

Setiap hari kelima sahabatnya selalu ada penguatan positif sahabat- sahabatnya kepada Risa. Sahabat yang mampu membuat Risa tertawa menghilangkan kesedihanya dan untuk Risa. Risa mengetahui bahwa kelima melindungi Risa. sahabatnya itu bukan dari golongan manusia. Respon Risa terhadap stimulus yang diberikan adalah iba terhadap cerita - cerita kelima sahabatnya. Ia semakin sayang pada kelima sahabatnya dan berjanji tetap akan menjadi sahabat meskipun ke lima sahabatnya bukan dari golongan manusia. Berikut ini kutipan yang menunjukkan hal tersebut.

"Dua tahun sudah kulalui harihari seperti ini, hidup berdampingan dengan sahabatsahabat yang hanya bisa dilihat oleh mataku."(Danur 2011:13)

"Hari ketika bukan rasa takut yang menyeruak di pikiranku, melainkan rasa iba dan rasa sayang yang mengusir hantu lokal yang sedang bersama Risa. begitu dalam hingga ingin kupunguti satu- satu kepala mreka sambil berbisik, Aku tetap sahabat beda dunia, sehingga perilaku Risa pada saat itu kalian."(Danur 2011:14)

"Dengan sedikit nekat akhirnya kucuba menggapai cita- cita dengan benar- benar serius merekam beberapa lagu yang kutulis, termasuk lagu yang kutulis untuk sahabat- sahabat kecilku." (Danur 2012:201)

"Aku dapat merasakan mataku yang menghangat karena air mata." (Danur 2011:203)

"Hidupku yang penuh warna kaget, senang. Risa menangis dan memeluk mereka.

bersama Peter, Hans, William, Hendrick, dan Janshen; temanteman tak kasat mata lainnya yang kini mulai bermunculan; keluarga kecilku yang jarang sekali kutemui; ketidaknyamananku dengan temanteman sekolahku; hingga konflik diri ini yang selalu bimbang dengan pertanyaan,"Sebaiknya, aku terus melanjutkan hidupku atau aku ikut ke dunianya Peter saja ya...?."(Danur 2011:16)

Stimulus dengan penguatan positif memotivasi banyak tingkah laku sehari - hari. Stimulus yang diberikan kelima sahabatnya membentuk respon Risa yakni menerima mereka. Hal tersebut terjadi karena respon - respon Rindang. Hal tersebut membentuk respon Risa

"Kuputuskan untuk kabur dari Peter dan Janshen pagi itu, juga kabur dari Pak Jamin yang sudah pasti akan menghujaniku dengan ceramah kedisiplinan, selalu dengan ceramah yang sama ketika aku terlambat masuk sekolah."..." Akhirnya kuputuskan untuk kabur dan melamun saja di lahan kosong itu."(Danur 2011:15)

Kutipan di atas mengungkapkan bahwa Stimulus dengan penguatan positif memotivasi timbulnya tingkah laku. Stimulus yang diterima oleh mata Risa berupa melihat lahan kosong dan 
untuk pergi ke lahan itu. Hal ini timbul karena Risa berusaha tidak memperdulikan Berikut

Risa malas untuk pergi sekolah.

"Bahkan aku masih menyimpan
baju berwarna krem penuh renda
yang dulu sempat mereka
hadiahkan untukk saat untuk
pertama kalinya aku menghadiri
pesta keluarga mereka di ruang
tamu rumahku suatu dini hari."
(Danur 2011:17)

Kutipan di atas mengungkapkan bahwa kebersamaan dan hadiah dari kelima sahabatsahabat ke Risa merupakan stimulus berkondisi dengan penguatan positif yang dibiasakan secara ajeg oleh mereka. Hal itu menimbulkan kenyamanan pada diri Risa yang menyebabkan timbulnya respon berupa percobaan bunuh diri. Ketika Risa gagal dalam percobaan bunuh dirinya itu, ia merasa sedih. Timbul perasaan kecewa pada diri Risa bahwa ia suatu saat akan berpisah dengan sahabatnya.

Makhluk halus semakin banyak yang menyenangkan berupa gangguan ketika Risa saat berdatangan, hanya ingin bercerita tentang kisah berkendara. Ia menjadi orang yang memiliki hidup. Kemampuan Risa melihat dunia lain yang perilaku cuek terhadap makhluk halus. Perilaku masih tetap meskipun Risa tidak lagi dapat tersebut disebabkan karena ia mulai tidak merasa melihat kelima sahabatnya. Kekecawaanya nyaman dengan kelebihan yang ada pada diri karena tidak bisa lagi melihat sahabatnya, ia Risa. Risa mulai menginginkan hidup yang mencoba acuh tak acuh terhadap cerita mereka. normal.

Respon yang seperti itu membuat ia menjadi sering dirasuki oleh makhluk halus.

Penguatan negatif makhluk halus terhadap Risa sering menimbulkan perilaku yang justru terpaksa. Penguatan negatif terjadi ketika respon diperkuat (sering dilakukan), karena diikuti oleh stimulus yang tidak menyenangkan. Stimulus yang di berikan oleh makhluk halus yang terus menerus menganggu dan memaksa untuk mendengarkan cerita mereka. Membuat
Stimulus Dapat Diterima oleh Alat Indra

"Sebagian besar dari mereka hanya
ingin menyampaikan keluh kesah
tentang kematian mereka yang tak
membuat mereka tenang, sebagian
kecil meminta pertolongan apa pun
itu bentuknya, sisanya menayakan
kepadaku kenapa mereka menjadi
seperti sekarang ini." (Danur
2011:74)

"Aku paling benci pada hantu yang menghantuiku seperti itu, datang tiba- tiba dan menghilang begitu saja." (Danur 2012:170) suara teriakan anak kecil itu masih mengganggu telinga dan kepalaku, terasa seperti masih berada di belakangku berteriak- teriak mencari mamanya... sangat mengganggu." (Danur 2011:171)

Kutipan di atas mengungkapkan bahwa penguatan negatif terjadi ketika respon diperkuat karena diikuti oleh stimulus yang tidak Telinga

Stimulus yang diterima tokoh Risa melalui alat indra telinga berupa cerita dari makhluk halus, mendengar tangisan jhansen. Satu persatu sahabat- sahabat Risa bercerita tentang kisah mereka selama masih hidup. Lamanya jalinan persahabatan mereka membuat respon
"Lebih menyebalkannya lagi, 
Risa menikamati saat saat berkumpul serta yang cenderung menyedihkan, sehingga Risa bisa mendengarkan cerita mereka. Merasa beruntung bersikap dewasa Seperti yang dikatakan oleh dapat mengenal mereka. stimulus berkondisi Skinner, bahwa penguatan positif memotivasi dibentuk oleh kelima sahabatnya terhadap Risa. banyak tingkah laku sehari - hari.

Hal itu membuat Risa merasa iba dan beruntung dapat mendengarkan cerita dari mereka. Berikut kutipan yang menunjukkan hal tersebut.

" Malam dini hari itu aku, Hendrick, dan Hans berlarian tertawa menikmati kebahagiaan yang mungkin semu bagi orang lain yang melihatnya, namun terasa nyata bagi kami bertiga."(Danur 2011:39)

Stimulus berkondisi berupa tangisan di tengah malam dengan penguatan positif dibentuk oleh Janshen. Ia ingin bercerita dengan Risa. Akhirnya Risa terbangun dan mengajak agar Jhansen naik ke tempat tidurnya dan Risa memeluk dan menyuruh Janshen bercerita. Risa semakin iba dan menjadi semakin menyayangi Jhansen sepenuh hati. Risa ingin menjadi pendengar yang baik bagi sahabatnya itu. Berikut bertemu dengan kelima sahabatnya. Perilakunya kutipan yang menunjukkan hal tersebut.

"Suara tangisnya semakin mengganggu, seolah sengaja ingin membangunkanku."(Danur 2011:58)

\section{Stimulus Dapat Diterima oleh Alat Indra Mulut}

Stimulus yang diterima tokoh Risa melalui alat indra mulut berupa komunikasi dengan makhluk halus. Perilaku tokoh Risa yang terlihat dari kutipan di bawah dibentuk oleh lingkungan yang ia rasakan nyaman. Perilaku tokoh Risa dibentuk dari stimulus dibiasakan secara ajeg dengan penguatan positif oleh makhluk halus. Menceritakan kisah semasa hidup

\begin{abstract}
"Kadang aku mengutuk kenapa harus aku yang memiliki kemampuan untuk melihat mereka...tapi di sisi lain, banyak sekali hal yang bisa kupelajari dari mereka." (Danur 2011:148)
\end{abstract}

\section{Perkembangan Kepribadian Tokoh Indigo}

Respon atau perilaku Risa dipengaruhi stimulus sehingga menimbulkan perkembangan kepribadian. Perkembangan kepribadian Risa terdapat pada sebelum mengenal kelima sahabatnya, mengenal, ditinggalkan dan bertemu kembali dengan kelima sahabatnya. Perkembangan kepribadian digambarkan pada awal, tengah, akhir cerita.

Pada awal cerita Risa belum pernah murung dan malas pergi kemana- mana. Risa lebih senang menyendiri. Di tengah cerita ia masuk pada stimulus yang diterima oleh mata berupa pertemuannya dengan kelima makhluk halus yang menjadi sahabatnya. Ia mulai nyaman dengan kelima sahabatnya. Setelah mengenal sahabatnya perilaku Risa menjadi lebih ceria. Janji yang tidak bisa Risa penuhi membuat ia ditinggalkan oleh kelima sahabatnya. Perilakunya mengutuk kemampuannya dan acuh pada makhluk halus yang datang menemui Risa. Pada akhir cerita ia bertemu lagi dengan kelima sahabatnya. Perilaku Risa menjadi semakin dewasa. 
PENUTUP

\section{SIMPULAN}

Berdasarkan pembahasan pada bab sebulumnya dapat diambil simpulan sebagai berikut:

1. Karakteristik seorang indigo yang terdapat pada tokoh utama, meliputi berkemauan keras, keras kepala, kreatif, dengan bakat artistik pada musik, bertindak berdasarkan intuisi atau psikis, cenderung mengalami insomnia dan mimpi buruk, memiliki riwayat depres dan pikiran- pikiran atau upaya bunuh diri, mencari persahabatan yang sejati, mendalam, dan bertahan lama. Pada karaktristik yang terdapat pada tokoh utama sebagai seorang indigo selurhnya masuk pada perilaku berkondisi. Karakteristik yang secara alamiah melekat pada diri Risa diperkuat oleh rangsangan dari luar, sehingga perilaku Risa sesuai dengan rangsangan yang ia dapat.

2. Perilaku Risa dipengaruhi oleh stimulus-stimulus yang berupa kondisi keadaan seseorang, dan kondisi psikis. Perilaku tokoh Risa merupakan respon yang terbentuk akibat pengaruh lingkungan atau stimulus berupa perilaku tokoh lain. Respon itu berkembang setelah memperoleh penguatan berupa perilaku tokoh Peter, William, Hans, Hendrick, Janshen dan Diah. Stimulus yang terdapat pada novel Danur dapat diterima oleh alat indra mata, telinga dan mulut. Pembentukan stimulus pada novel
Danur ialah bersifat ajeg, positif, dan berjarak.

3. Lingkungan tempat Tokoh Risa berperan penting dalam membentuk kepribadiannya. Lingkungan mempunyai pengaruh besar dalam kehidupan tokoh Risa. Hal tersebut terbukti pada peristiwa tokoh Risa sebelum mengenal kelima sahabatnya, mengenal, ditinggalkan dan bertemu kembali dengan kelima sahabatnya.

\section{Saran}

1. Hasil penelitian ini diharapkan dapat dijadikan sebagai tambahan referensi bagi mahasiswa yang melakukan penelitian sejenis, terutama yang berhubungan dengan Perilaku serta menambah pengetahuan tentang Psikologi kepribadian B.F Skinner. Teori ini dapat membantu kita memahami bahwa perilaku seseorang disebabkan oleh stimulus yang mengawalinya. Oleh karena itu diharapkan teori Psikologi kepribadian B.F Skinner ini dapat digunakan untuk menganalisis karya sastra yang lain.

2. Bagi calon peneliti sastra, diharapkan dapat mengembangkan lebih lanjut dengan menggunakan teori yang lain tetapi masih dalam lingkup penelitian mengenai perilaku tokoh dalam novelnovel yang lain.

\section{DAFTAR PUSTAKA}

Aminuddin. 1990. Sekitar Masalah Sastra: beberapa Prinsip dan Model Pengembangannya. Malang: Yayasan Asih Asah Asuh. 
Ratna, Nyoman Kutha. 2012. Teori, Metode, dan Teknik Penelitian Sastra. Yogyakarta: Pustaka Belajar.

Saraswati, Risa. 2011. Danur. Jakarta: Bukune.

Virtue, Doreen. 2011. Identifikasi dan Penanganan bagi Anak- anak Indigo. Pengalih bahasa: Lily Endang Joeliani. Jakarta: PT Bhuana Ilmu Populer.

Wawan, A dan Dewi M. 2010. Teori dan Pengukuran Pengetahuan, Sikap, dan Perilaku Manusia. Yogyakarta: Nuha Medika.

Wellek, Rene dan Austin Warren. 1995. Teori Kesusastraan. Pengalih bahasa: Melani Budianta. Jakarta: PT Gramedia Pustaka Utama.

Yusuf, Syamsu dan Juntika Nurihsan. 2008. Teori Kepribadian. Bandung: PT. Remaja Rosakarya Offset

Sugihastuti dan Suharto. 2013. Kritik Sastra Feminis Teori dan Aplikasinya. Yogyakarta: Pustaka Pelajar.

Tasharofi, Parmis. 2014. "Domestic Violence in Zora Neale Hurston's Their Eyes Were Watching God: A Feminist Reading”. International Journal of Applied Linguistics \& English Literature. Vol. 3 No. 4; July 2014. ISSN 2200-3592 (Print), ISSN 2200-3452 (Online). Australian International Academic Centre, Australia.

Utami, Trie. 2010. Dunia Padmini. Jakarta: Pustaka Sastra.

Wahono, David Yulia Christianto, Nas Haryati, Sumartini. 20015. "Pengaruh Kekuasaan Laki-Laki Terhadap Perempuan dalam Novel The Chronicle of Kartini karya Wiwid Prasetyo: Kajian Feminisme". Jurnal Sastra Indonesia. JS14 (1). 2015. ISSN 22526315. Universitas Negeri Semarang.

Yuliastuti, Fitri. 2005. Citra perempuan dalam novel Hayuri karya Maria Etty.Skripsi. Fakultas Sastra Dan Seni Rupa Universitas Sebelas Maret Surakarta.
Zuraida, Tia Ratna. 2012. Pemberontakan perempuan dalam novel Perempuan Badai karya Mustofa Wahid Hasyim: Kajian feminisme. Skripsi. FBS: Universitas Negeri Semarang. 